\title{
Limitation of West Nile Virus transmission through transfusion of blood/blood components - Polish recommendations
}

\author{
Piotr Grabarczyk ${ }^{1} \oplus$, Jowita Niczyporuk ${ }^{2} \oplus$, Piotr Czupryna ${ }^{3} \odot$, Elżbieta Lachert ${ }^{4} \oplus$, \\ Magdalena Łętowska ${ }^{4} \odot$ \\ ${ }^{1}$ Department of Virology, Institute of Hematology and Transfusion Medicine in Warsaw \\ ${ }^{2}$ Department of Poultry Diseases, National Veterinary Institute — National Research Institute in Puławy \\ ${ }^{3}$ Department of Infectious Diseases and Neuroinfection, Medical University of Białystok \\ ${ }^{4}$ Department of Transfusion Medicine, Institute of Hematology and Transfusion Medicine in Warsaw
}

\begin{abstract}
For many years, the West Nile virus (WNV) has been the focus of attention of specialists in transfusion medicine due to documented transmission of the virus through blood and blood components. In the recent years, a periodic increase in the number of infections in Europe (2018) has been reported as well as outbreaks of infections among animals and people in areas where the presence of the virus has not been observed so far.

The study updates biological and epidemiological data on WNV published in 2013 (Journal of Transfusion Medicine) [1] and suggests measures to be taken to prevent the spread of WNV human infections via transfusion if WNV infections occurred in Poland. National recommendations were based on international guidelines developed by specialists in transfusion medicine and infectious diseases in cooperation with research centers that monitor epidemiology of the virus.
\end{abstract}

Key words: West Nile Virus, blood donors, transfusion safety, Polish recommendations

J. Transf. Med. 2020; 13: 239-248

\section{General information on WNV}

West Nile Virus (WNV) was first isolated in 1937 from the blood of a sick woman in the West Nile Province of Uganda [2]. Recent epidemiological data indicate the persistence of the epidemic in some regions of Europe and North America. In some areas the epidemic seems to be even more intensive. Up to date in Poland no cases of human WNV infections have been reported, however results of animal studies indicate that the virus is circulating in the ecosystem. Moreover, the interest in this virus in our country is justified due to the ongoing climatic changes and the adaptive capacity of the virus.

The West Nile virus, a flavivirus of the Flaviviridae family, which also includes dengue virus (DENV), Japanese encephalitis virus (JEV), tick-borne encephalitis virus (TBEV), Murray Valley encephalitis virus or Yellow Fever virus (YFV). WNV belongs to the serocomplex of Japanese encephalitis, which includes several clinically significant viruses responsible for human encephalitis such as: Japanese encephalitis virus, St. Louis encephalitis virus, the Murray Valley encephalitis virus and the Kunjin virus (subtype of WNV found in Au-

Correspondence address: dr hab. n. med. Piotr Grabarczyk, Head of the Department of Virology at the Institute of Hematology and Transfusion Medicine in Warsaw, Chocimska Street 5, 00-957 Warszawa, e-mail: pgrabarczyk@ihit.waw.pl, phone: 223496 685, fax: 223496603

Translation: mgr Krystyna Dudziak 
stralia - responsible for the so-called Australian encephalitis). Close antigenic relationship between these viruses is responsible for serological cross-reactions [3].

West Nile virus is a small enveloped virus (40-60 $\mathrm{nm}$ in diameter) which belongs to the group of arboviruses, i.e. anthropod-borne viruses [4]. The WNV is constituted by a single-stranded RNA molecule of positive polarity. This RNA molecule of about 11000 nucleotides in length encodes one polyprotein.

Eight phylogenetic lineages of the virus have been identified. Classification of individual lineages was based on the analysis of the gene sequence encoding structural and nonstructural proteins of the WNV-1-5 lineage [5]. Lineage 1 is pathogenic for domestic and wild animals as well as for humans. Currently, it is spread all over the world and closely related to the occurrence of West Nile fever in humans. It includes highly virulent strains. Based on phylogenetic and geographic analysis, the lineage 1 strains were further divided into three clades marked as $1 \mathrm{a}, 1 \mathrm{~b}$ and $1 \mathrm{c}$. Clade $1 \mathrm{a}$ represents six clusters - branch 1 are strains from Europe and Africa, branch 2 - strains from Morocco, France, Portugal, Italy, Russia and Romania, branch 3 are strains from Russia, branch 4 - strains isolated in North and South America, Israel, Tunisia and Hungary, branch $5-$ contains strains from the Central African Republic, while branch 6 - strains isolated in Senegal and Nigeria. Classified as clade $1 \mathrm{~b}$ is the Kunjin virus, which is observed to spread in Australia and Oceania. Clade 1c contains strains from India [6]. Lineage 2 includes enzootic strains isolated in sub-Saharan Africa and Madagascar marked as weakly virulent [5]. Since 2004, these strains have also been isolated in Central and Eastern Europe. Animal trials/ /studies suggest however, that virulent strains may be found in both the WNV-1 and WNV-2 lineages. Mutations in genome regions are responsible for strengthening the virulence of WNV strains; the most important is the substitution of amino acid for proline in the nonstructural protein NS3 at position 249. Another important mutation affecting WNV strain virulence is glycosylation of $\mathrm{E}$ glycoprotein at E154. This lineage has spread in Europe over the last 10 years, causing dangerous outbreaks of infection in humans and horses [7]. Branch 2a represents the strains from Madagascar designated MAD78, branch $2 b$ represents the strains from South Africa (SA58b) and Cyprus (CYP68), and branch 2c contains strains isolated from Madagascar (MAD88). The 2d branch contains strains from the Democratic Republic of the Congo (CON58), South Africa (SA58A, SA89, SA00), Central African Republic (CAR82), Uganda (UGA37), Senegal (SEN90), Russia (RUSV07), Hungary (HUN04), Greece (GRE10) and Italy (ITA11b) [8].

WNV lineage 3 described as Rabensburg includes strains isolated from the Culex pipiens and Aedes rossicus mosquitoes in the Czech Republic and the Czech-Austrian border [9, 10].

WNV lineage 4 includes strains isolated from the Dermacentor marginatus ticks in the south-western Caucasus (Russia), from the Uranotaenia unguiculata mosquitoes and from the blood of frogs in the Volga River valley [11, 12]. These strains are not pathogenic to humans.

The 13 strains isolated in India both from humans and Culex mosquitoes were classified as WNV lineage 5 [13].

The genetic material of the virus representing lineage 6 was also isolated from the population of Culex pseudovishnui mosquitoes. So far, no pathogenicity for humans or animals has been reported [14].

Lineage 7 is the African Koutango virus isolated from gerbils blood in the Koutango region of Senegal and Somalia. Studies demonstrated its virulence to be higher than that of the WNVNY99 genotype which was responsible for one of the largest epidemics in the United States [14].

Lineage 8 of the virus is called the Yaounde Lineage first isolated as a Yaounde virus from birds, mammals and Culex and Aedes mosquitoes in Cameroon, Central African Republic, Democratic Republic of the Congo, Senegal, Ghana and Côte d'Ivoire. So far, its pathogenicity for humans has not been demonstrated [15].

\section{Life cycle}

The primary reservoir of the virus are tropical and migratory birds, which do not develop symptoms of the disease despite high viral load and long-term infection. On the contrary, birds outside the endemic territory are very susceptible to infection and manifest weakness, convulsions, ataxia, change in appearance (e.g. S-shaped neck) and present unusual behavior (eg. swimming in circles) $[16,17]$. Massive demise of birds followed by death of other animals (mostly horses) indicate the high probability of human infection in the near future [16]. The virus is capable of infecting over 300 bird species [18]. 
The vector for WNV are blood-sucking flies, mainly mosquitoes and black flies. The virus is transmitted by over 150 species of mosquitoes, 12 of which are found in Poland. Particularly significant for transmission of the virus infection are mosquitoes that feed on the blood of both birds and mammals (e.g. Culex spp., Culiseta spp., Anopheles spp.) [16, 19]. Mosquitoes become infected with WNV by sucking blood of infected birds, which (with the exception of several species) produce viral loads high enough to infect mosquitoes [20]. The virus replicates in the midgut epithelial cells of the mosquito, then spreads via haemolymph throughout the body to salivary glands, where it is secreted in high concentrations into the mosquito's saliva. The newly hatched individuals are already infected [17, 21]. Mosquito bite transfers the virus from salivary glands into the skin of the next host [22]. Some casual hosts, such as humans and horses, may show clinical signs of infection, but the viral load is insufficient to infect the vector.

The duration of virus transmission period (during the year) is climate-dependent. In temperate, maritime continental climate zones, the best conditions for virus replication are during the summer, when the temperature is high. On the other hand, in tropical and subtropical climate zones, virus transmission continues all year round [16]. Temperature is the factor that either limits or enhances the capacity of viral transmission by/through mosquitoes. Local temperatures during the mosquito feeding cycle are therefore crucial for determination of the course of viral transmission [23].

Until recently, the virus was believed to replicate in a mosquito at round-the-clock temperature of at least $22^{\circ} \mathrm{C}$ for 12 days [24]. Recent studies demonstrate that the adaptive capacity of the virus is greater than was previously thought. It is currently believed that the virus replicates at a temperature below $14.3^{\circ} \mathrm{C}$ during the 12 -day feeding period of the vector [23].

Moreover, it has been proven that in higher temperatures the vectorial capacity of the mosquito increases. Even a slight temperature increase has been shown to have relatively large impact on WNV transmission [25]. In light of new observations regarding the relationship between ambient temperature and WNV transmission by mosquitoes, it is easy to explain cases of human infection in cooler climates, e.g. Canada, where a total of 450 clinical cases and asymptomatic WNV infections were reported in 2012 alone [26]. According to projec- tions, the territory of WNV infection in Europe will expand with climate change. In the third decade of this century WNV infections are predicted in the southern regions of Poland [27].

The blood of birds, mammals and other animals on which the infected mosquito feeds becomes infected with WNV. Mammals are casual hosts for the virus. Under natural conditions transmissions from human-to-human do not occur. Virus transmission may however occur through transfusion of blood and blood components as well as organ transplants. Cases of intrauterine and transplacental infection transmission have also been reported [28] as well as infection via breast feeding and contact with virus-infected biological material (laboratory staff) [29].

\section{Current epidemiological situation in Poland and Europe}

According to the European Center for Disease Prevention and Control (ECDC), the WNV infection cases in 2018 were more frequent than during the transmission seasons of several last years. Most likely this was because the epidemic season lasted longer. The first case of infection was reported late May and the last one in December.

Eleven EU/EEA Member States reported a total of 1,605 WNV infections; $1,548(96 \%)$ of them acquired locally and $85 \%(\mathrm{n}=1,311)$ confirmed). Most locally acquired cases were reported in Italy, Greece and Romania. As compared to 2017, there was a 12 -fold increase in the number of cases from Italy, a 7 -fold increase for Greece and a 4-fold increase for Romania. The 2018 reports include 992 cases of neuroinvasive disease, 468 non-invasive cases and 83 infections among blood donors [30].

In 2019, the EU Member States and neighboring countries reported 463 cases of WNV infection among humans: Greece (223), Romania (66), Italy (53), Hungary (36), Cyprus (16), Bulgaria (5), Austria (4), Germany (4), France (2) and Slovakia (1). Neighboring countries reported a total of 53 infection cases: Serbia (27), Israel (10), Turkey (10) and North Macedonia (6). During the same period, $50 \mathrm{WNV}$ related deaths were reported. During the same transmission season, both Germany and Slovakia reported the first autochthonous WNV infections [31].

\section{WNV epidemiological studies in Poland}

First reports that indirectly point to the presence of WNV in Poland are derived from the mid1990 studies on the population of house sparrows 
(Passer domesticus) and Euroasian tree sparrows (Passer montanus). The studies were performed on the edge of the Kampinos Forest (Łomianki/ /Warsaw). Both the above species are sedentary bird populations. Anti-WNV antibodies were identified in $12.1 \%$ of Euroasian tree sparrows and $2.8 \%$ of house sparrows [32]. During 2006 studies in a population of 97 free-living birds (representing 10 species), specific antibodies were found in 5 individuals $(5.2 \%)$ (three white storks, one mute swan and one crow). Four came from the Bird's Sanctuary in the Warsaw Zoological Garden [33]. In 2009, the NRT-PCR method for identification of WNV in the brain tissue of infected birds was first described in Poland [34]. In the years 2004-2009, screening tests for the presence of viral genetic material in about 15,000 female mosquitoes were performed in the Kujawsko-Pomorskie, Warminsko-Mazurskie, Mazowieckie and Podlaskie provinces. In 2007-2010 studies were performed on the brain tissue of 2,140 wild birds from various regions of Poland. No cases of viral RNA were reported [35, 36]. Studies on the same subject were continued in 2011-2015 and consisted in testing of 7,240 samples; no genetic material of the virus was detected [37].

Serological screening tests performed in 2015 detected WNV antibodies in 63/474 (13.29\%) serum samples of wild birds and in $1 / 378(0.26 \%)$ horse serum samples. [37]. Further studies confirmed the presence of specific antibodies in domestic and wild animals and this is evidence of past infection. Up to date however, no case of active infection has been documented in Poland [37, 38].

So far, research studies on humans are scarce. WNV diagnostics in Poland is impeded by cross-reaction of antibodies against the tick-borne encephalitis virus (TBEV) which is endemic, e.g. in Podlaskie and Warmińsko-Mazurskie provinces [39].

Approximately 3-15\% of ticks are estimated as TBVE-infected [40]. The incidence of tick-borne encephalitis in Poland is calculated at 0.69 per 100,000 inhabitants (2019 data of the National Institute of Public Health - National Institute of Hygiene) with most cases recorded in the two above mentioned provinces. The percentage of occupationally exposed seropositive inhabitants of endemic areas (not vaccinated against TBEV) ranges from $25 \%$ to even $81 \%$ [41].

Tick-borne encephalitis symptoms resemble those of WNV infection and the disease is usually two-phase. The first phase manifests with flu-like symptoms associated with the presence of the virus in the blood. During the second phase, the virus penetrates into the central nervous system and may present as meningitis, encephalitis, or encephalomyelitis [42]. TBEV antibodies are detected in TBEV infected patients as well as vaccinated persons (since the 1990ies practically all foresters are systematically vaccinated against TBEV).

That is the reason why any seropositive WNV case needs to be confirmed with the Plaque Reduction Neutralization Test, so far unavailable in Poland.

In 2005, at the Department of Infectious Diseases and Neuroinfection of the Medical University of Bialystok, high levels of IgM antibodies against WNV and Lyme-disease were detected in a female patient with recurrent fever, headaches and muscle aches. However, no definitive confirmation of WNV infection was reported by the reference laboratory [29]. In 2006, 93 forest workers from the Świętokrzyskie and Podlaskie provinces were screened for WNV IgG antibodies in serum - 29 (31\%) samples were found WNV positive with ELISA method. The results were then verified by indirect immunofluorescence assay (IFA) at the National Reference Laboratory for zoonotic diseases in Budapest, Hungary. Specificity of the primary reactive result was confirmed in 5 samples; in two anti-TBE IgG were also detected, and in the other 3 the results were indeterminate [16]. In 2015, WNV antibodies were detected in 14/42 patients with meningitis [43, 44]. Subsequent serological and molecular biology tests in patients with neurological symptoms did not directly confirm WNV infection in Poland $[45,46]$.

\section{WNV and safety of transfusions and transplants}

During the 2002 North American epidemic, the first cases of transfusion-related WNV infections were reported (TT-WNV, transfusion transmitted WNV). 23 TT-WNV infection cases were described following transfusion of: red blood cells (RBCs), including leukocyte reduced RBCs; platelet concentrate (PC) as well as fresh frozen plasma (FFP) [47]. Another 11 TT-WNV cases were reported in 2003-2008. In the period 2003-2012, a total of 3,725 cases of WNV infection in blood donors were reported [48]. Initially, the US Food and Drug Administration (FDA) recommended that blood for clinical use must not be collected from donors presenting fever and headache during the week preceding donation. Additionally, FFP units from regions of particularly severe epidemic were withdrawn from use for manufacturing of blood 
Table 1. Pathogen inactivation methods used for reduction of TT-WNV risk (transfusion-transmitted WNV)

\begin{tabular}{llcc}
\hline $\begin{array}{l}\text { Inactivation method/ } \\
\text { /pathogen reduction }\end{array}$ & Mechanism of action & $\begin{array}{c}\text { Effectiveness } \\
\text { (reduction in viral } \\
\text { load - log10) }\end{array}$ & $\begin{array}{c}\text { Blood } \\
\text { component }\end{array}$ \\
\hline $\begin{array}{l}\text { Methylene Blue } \\
\text { (System Theraflex MB Plas- } \\
\text { ma, Macopharma, France) } \\
{[52,53]}\end{array}$ & $\begin{array}{l}\text { Visible light }(590-670 \mathrm{~nm} \text { ); free oxygen radi- } \\
\text { cals damage nucleic acid chains of viruses to } \\
\text { interrupt their transcription and replication }\end{array}$ & $>6,5$ & FFP \\
$\begin{array}{l}\text { Amotosalen Hydrochloride } \\
\text { (derivative of psolaren, Sys- }\end{array}$ & $\begin{array}{l}\text { Ultraviolet light (320-400 nm), unbreakable } \\
\text { cross-links with the nucleic acids of pathogens }\end{array}$ & $>5,2$ & FFP and PC \\
$\begin{array}{l}\text { are formed, which prevents pathogen replica- } \\
\text { [54, 55] }\end{array}$ & & \\
$\begin{array}{l}\text { Riboflavin } \\
\text { (vitamin B2, System Mirasol }\end{array}$ & $\begin{array}{l}\text { Ultraviolet light (265-370 nm), pathogen re- } \\
\text { plication is inhibited as result of reactions with } \\
\text { nucleic acids and surface structures }\end{array}$ & 5,19 & FFP and PC \\
\hline
\end{tabular}

products. The decisions most likely helped to avoid further transmission as markers of severe WNV infection were detected in 3 of 1,500 donations [49].

In mid-2003, nucleic acid testing (NAT) was implemented in minipools of 6 ((PCR) and 16 (TMA) donations. The sensitivity of tests soon proved to be insufficient, which resulted in post-transfusion WNV infection cases. [50]. The above is indicative of the high infectivity of WNV transmitted through blood, particularly during the window period - the early stage of infection before appearance of antibodies.

Although most TT-WNV cases occur in the window period, in vitro studies demonstrate that the presence of antibodies in transfused blood/ /blood components does not offer complete protection against infection transmission [51].

\section{Inactivation}

Viral level/load of WNV in the window period can reach $10^{8}$ to $10^{10}$ virions $/ \mathrm{ml}$. Assessment of the infection risk, dynamics and virus infectivity demonstrates that in some cases a titer reduction by $6 \log$ effectively reduces the risk of transfusion-transmitted infection whereas in others it may prove insufficient. For WNV viremia is not likely to exceed $4-5 \mathrm{log} / \mathrm{ml}$ even at infection peak. Such viral level does not last long and the virus is neutralized. Routine methods of pathogen inactivation (used in Theraflex MB Plasma, Mirasol and Intercept systems) are highly effective for WNV and exceed $5 \log$ (Table 1). Like all other methods, pathogen inactivation based solely on UVC (no photosensitizing agents) inactivates viruses to a different extent. This inactivation method is confirmed to be effective for: Vesticular Stomatis Virus (VSV), Sindbis virus and $\mathrm{HCV}$. On the other hand, the UVC method was found less effective against HIV and WNV. The Theraflex UV Platelets system is effective for inactivation of small, non-enveloped DNA/RNA viruses such as: plum-pox virus (PPV): on average - reduction by $4-5$ logs.

Table 1 presents the mechanism of action, effectiveness in reducing TT WNV infectivity and pathogen inactivation used for individual blood components.

Effectivity assessment of inactivation methods with regard to individual viruses (WNV included), should take into account: the degree of reduction ( $\log 10)$, change of viral load in subsequent stages of infection, sensitivity of screening tests and algorithm for donor eligibility.

It should be kept in mind that even if molecular biology assays (NAT) are used for HIV, HCV and HBV detection there still remains the risk of infection during the window period. Thus, by combining the advantages of molecular biology assays (NAT) for high viremia with advantages of inactivation methods for lower viremia, it is possible to eliminate window-period infections and markedly limit the transmission of new pathogens.

For WNV, implementation of one of the three pathogen inactivation methods presented in table 1 will contribute to significant reduction of the risk associated with FFP transfusion whereas the use of riboflavin or psoralen-based inactivation methods will significantly reduce the risk of WNV transmission associated with PC transfusion.

It should be kept in mind that pathogen inactivation methods for whole blood and packed red blood cells are still unavailable. 
Table 2. Criteria for assessment of the WNV infection risk in an area

\begin{tabular}{lcccc}
\hline $\begin{array}{l}\text { Classification } \\
\text { of the area } \\
\text { in terms of WNV } \\
\text { infection risk }\end{array}$ & $\begin{array}{c}\text { Environmental condi- } \\
\text { tions (a) which favor } \\
\text { human transmission } \\
\text { of WNV }\end{array}$ & $\begin{array}{c}\text { Pathogen (b) - } \\
\text { presence in vectors } \\
\text { and/or in animals }\end{array}$ & $\begin{array}{c}\text { WNV Transmission } \\
\text { (c) to humans }\end{array}$ & $\begin{array}{c}\text { Seasonal (d) repeatabi- } \\
\text { lity of WNV transmis- } \\
\text { sion among humans }\end{array}$ \\
\hline No risk & - & - & - & - \\
Predisposed & + & - & - & - \\
Imperilled/endangered & + & + & + & - \\
Affected by the disease & + & + & + & + \\
Endemic & + & + & & + \\
\hline
\end{tabular}

\section{Assessment of WNV infection risk}

The actual level of WNV infection risk in an area depends on environmental conditions, the presence of arthropod vectors and pathogens, prior transmission to humans, and seasonal recurrence of the disease in the region.

An area at risk is a territory where people are at either high or low risk of being infected with locally-acquired/autochthonous WNV (Table 2). Recommendations for restrictions regarding WNV transmission through blood depend on the category of risk area.

Four (4 )categories of risk areas have been defined:

I. A predisposed area is a risk area where existing conditions might facilitate the transmission of WNV to humans, but the respective pathogen has not been detected. Conditions favoring transmission are receptivity and/ or vulnerability of the area. Receptivity of an area is the presence and/or spread of arthropod vectors and the existence of other ecological and climatic factors favoring WNV transmission to humans. Vulnerability of the area means proximity to areas where WNV infection is present and/or frequent influx of infected individuals (groups) or infected arthropods.

II. An imperiled/endangered area is a risk area where the pathogen has been detected in vectors, or transmission of the pathogen to animals has been detected, or the transmission of the pathogen to humans has occurred within the last 5 years.

III. The affected area is the risk area with ongoing transmission of WNV to humans. This means that there has been at least one autochthonous human WNV case as a result of local transmission in the area according to the agreed, standardized and disease-specific case definition. Under exceptional circumstances, a probable case can be used to determine transmission but only in specific and agreed situations when case confirmation cannot be performed within a reasonable time.

IV. An endemic area is the area where WNV transmission to humans has been ongoing for 5 seasons.

The risk of WNV transmission to humans in an area should be assessed regularly for each season of infection transmission. Considering the above criteria, the territory of Poland should be classified as predisposed area as it meets the criteria of vulnerability - there are 12 species of mosquitoes capable of transmitting the WNV and during prolonged summer heat waves, the ecological and climatic conditions may favor WNV transmission to humans. Up to date however, no respective pathogenic agent has been detected on the territory of the Republic of Poland; all RNA virus detection tests have been negative. [see above: section: "Epidemiological studies of the West Nile Virus in Poland"]. There has recently been a change regarding the vulnerability criterion for Poland. In the previous years, no WNV infections were identified in the countries bordering with Poland, and no significant influx of infected people and/or infected arthropods had been reported. In the last two years however, (2018-2019), autochthonous human WNV were reported in the Czech Republic and Slovakia. Epidemics of horse and bird infections were observed in Germany [57, 58].

\section{Recommendations for reducing blood transmission of WNV}

The recommendations were based on the document West Nile Virus and Blood Safety: Introduction to Preparedness Plan in Europe, 2012 [59] 
Table 3. Measures to ensure blood safety during the WNV season (based on: [62])

\begin{tabular}{|c|c|c|c|}
\hline Measures & $\begin{array}{l}\text { Risk-free area/ } \\
\text { /predisposed area }\end{array}$ & Imperilled area & $\begin{array}{l}\text { Affected/endemic } \\
\text { area }\end{array}$ \\
\hline Deferral of residents & No & No & $\begin{array}{l}\text { Suspension of } \\
\text { blood collection }\end{array}$ \\
\hline Deferral of donors returning from affected areas & 28 days & 28 days & 28 days \\
\hline $\begin{array}{l}\text { NAT screening for large numbers of donors returning } \\
\text { from affected areas (to ensure blood supply) }\end{array}$ & To be considered & To be considered & Recommended \\
\hline $\begin{array}{l}\text { NAT screening of quarantine donations and retrospec- } \\
\text { tive NAT testing of plasma samples }\end{array}$ & No & To consider & Yes \\
\hline $\begin{array}{l}\text { Pathogen inactivation procedures (plasma and plate- } \\
\text { lets) }\end{array}$ & No & To be assessed & To be assessed \\
\hline $\begin{array}{l}\text { Crisis management team formed in in the appropriate } \\
\text { competent authority }\end{array}$ & $\begin{array}{c}\text { No, unless a large } \\
\text { number of donors } \\
\text { return from affected } \\
\text { areas }\end{array}$ & Not applicable & Yes \\
\hline $\begin{array}{l}\text { Informing other Member States (competent authori- } \\
\text { ties) on implementation of NAT screening }\end{array}$ & Yes & Yes & Yes \\
\hline
\end{tabular}

*unless NAT screening is implemented

developed during meetings of the Working Group on Blood Safety and WNV (EU), which took place on 25-26 January 2012 in Thessaloniki. Active in the discussions and preparation of the uniform approach to the issue were experts from countries affected by the WNV epidemic: Greece, Italy, Romania and France. The recommendations are the second version of the document of 2011 [60]. The Preparedness Plan includes among others a set of guidelines aimed at limiting the WNV blood transmission in Europe. These guidelines should be implemented in Poland as well.

Blood safety measures (Table 3) include:

- detailed epidemiological interview for blood donors;

- deferral of potentially exposed blood donors and utilization of infected donations;

- implementation of laboratory screening methods eg. nucleic acid testing (NAT);

- implementation of pathogen inactivation methods;

- appeal to donors to report any disease symptoms occurring after donation;

- haemovigilance.

\section{Temporary donor deferral}

Blood collection in non-affected areas (areas: with no risk, predisposed, imperiled/endangared):

- donor deferral for 28 days of leaving the area affected with ongoing WNV human transmission (Directive 2004/33/WE);
- every blood establishment should be informed on the spread of WNV to humans ( updated maps);

- people with recognized WNV infection can be restored to blood donation after 120 days of diagnosis [61].

Blood collection in affected and endemic areas:

- geographic donor deferral - national health authorities and other health care providers define a deferral season for citizens living in affected areas during virus transmission season, unless WNV NAT screening had been introduced as an alternative measure.

\section{Other preventive measures}

- Look-back procedure in cases of confirmation or suspicion of transfusion transmission with regard to samples collected within 120 days prior to donation which was found reactive in individual donation NAT (ID-NAT) (FDA Guidelines for Industry, 2009).

- Fever, flu-like/other symptoms should be reported to the blood establishment within 15 days of donation.

- Quarantine of blood components collected prior to outbreak of WNV epidemic. Data reports on a special reporting template addressed to competent authorities and related to activities performed on non-affected areas during ongoing WNV human transmission (Directive 2005/61/WE) [59]. 


\section{Measures for prevention of WNV transmission through transfusion in the event WNV infection is detected on the territory of Poland}

As of now, Poland meets the criteria for predisposed area - with the risk of autochthonous WNV infection in animals and humans. If WNV is detected in animals and/or vectors, our country will be classified as imperiled area. Immediately an educative campaign must be launched to remind blood donors to report any WNV infection symptoms (headache, fever) prior to blood donation or within two weeks of donation.

The area is considered affected if WNV infection is confirmed in humans. In line with international guidelines set out above, the following actions should then be taken:

1) no blood or blood components should be collected in the district which reported autochthonous WNV infection as well as in neighboring districts;

2) the Institute of Hematology and Transfusion Medicine (IHTM) will inform all blood establishments about any occurrence of an autochthonous WNV infection;

3) country-wide temporary deferral (28 days) should be implemented for donors and donor candidates who spent at least one night in the district, where autochthonous WNV infection case was reported as well as neighboring districts.

4) actions 1) and 3) should be continued until the end of the epidemic season (end of October) of the year in which autochthonous WNV infection was identified on the territory of Poland;

5) implementation of WNV RNA screening during epidemic period should be considered for plasma of donors living or staying at least one night in a district, where autochthonous WNV infection was identified. In single cases ( $<10$ ), MP testing (4 or 6 donations) should be sufficient. With higher number of infections, it is recommended to consider testing in individual donations. The methodology of WNV RNA testing should be consulted with IHTM.

6) following implementation of WNV RNA testing, blood collection can be resumed and deferral related to traveling to WNV infected areas can be lifted;

7) a crisis management team should be established in the event of an epidemic among wild or domestic animals and/or $>10$ cases of WNV human infection. The aim is to determine the method of monitoring the epidemiological situation and measures to prevent transfusion transmitted WNV in Poland.

Activities related to prevention of transfusion transmitted WNV should be consulted with IHTM.

The epidemiological situation in Europe is dynamic and the epidemiological risk status of neighboring countries is undergoing changes. The forecasts for Poland seem unfavorable, it is therefore necessary to develop a more detailed plan of action in the event of the occurrence of autochthonous WNV infection cases. Such plan must be updated in cooperation with appropriate national epidemiological services, experts in infectious diseases and veterinary services.

\section{References}

1. Tkaczuk K, Sulkowska E, Lachert E, et al. Wirus Zachodniego Nilu a bezpieczeństwo przetoczeń krwi i jej składników. J Trans Med. 2013; 6 (3): 69-84.

2. Smithburn KC, Hughes TP, Burke AW, et al. A neurotropic virus isolated from the blood of a native of Uganda 1. Am J Trop Med Hyg. 1940; s1-20(4): 471-492, doi: 10.4269/ajtmh.1940. s1-20.471.

3. Martin DA, Biggerstaff BJ, Allen B, et al. Use of immunoglobulin $m$ cross-reactions in differential diagnosis of human flaviviral encephalitis infections in the United States. Clin Diagn Lab Immunol. 2002; 9(3): 544-549, doi: 10.1128/cdli.9.3.544-549.2002, indexed in Pubmed: 11986257.

4. Knap JP, Kubica-Biernat B. [Did West Nile Fever (WNF) appear in Poland? Position of the Expect Committee appointed by the Chief Sanitary Inspector]. Przegl Epidemiol. 2003; 57(3): 399-404, indexed in Pubmed: 14682157.

5. De Filette M, Ulbert S, Diamond M, et al. Recent progress in West Nile virus diagnosis and vaccination. Vet Res. 2012; 43: 16 , doi: 10.1186/1297-9716-43-16, indexed in Pubmed: 22380523.

6. May FJ, Davis CT, Tesh RB, et al. Phylogeography of West Nile virus: from the cradle of evolution in Africa to Eurasia, Australia, and the Americas. J Virol. 2011; 85(6): 2964-2974, doi: 10.1128/ JVI.01963-10, indexed in Pubmed: 21159871.

7. Mentoor JLD, Lubisi AB, Gerdes T, et al. Full-genome sequence of a neuroinvasive West Nile Virus Lineage 2 strain from a fatal horse infection in South Africa. Genome Announc. 2016; 4(4), doi: 10.1128/genomeA.00740-16, indexed in Pubmed: 27469963.

8. McMullen AR, Albayrak H, May FJ, et al. Molecular evolution of lineage 2 West Nile virus. J Gen Virol. 2013; 94(Pt 2): 318-325, doi: 10.1099/vir.0.046888-0, indexed in Pubmed: 23136360.

9. Weissenböck H, Hubálek Z, Bakonyi T, et al. Novel flavivirus or new lineage of West Nile virus, central Europe. Emerg Infect Dis. 2005; 11(2): 225-231, doi: 10.3201/eid1102.041028, indexed in Pubmed: 15752439.

10. Rudolf I, Bakonyi T, Sebesta O, et al. West Nile virus lineage 2 isolated from Culex modestus mosquitoes in the Czech Republic, 2013: expansion of the European WNV endemic area to the North? Euro Surveill. 2014; 19(31): 2-5, doi: 10.2807/1560-7917. es2014.19.31.20867, indexed in Pubmed: 25138970.

11. Pesko KN, Ebel GD. West Nile virus population genetics and evolution. Infect Genet Evol. 2012; 12(2): 181-190, 
doi: 10.1016/j.meegid.2011.11.014, indexed in Pubmed: 22226703.

12. Chancey C, Grinev A, Volkova E, et al. The global ecology and epidemiology of West Nile virus. Biomed Res Int. 2015; 2015: 376230, doi: 10.1155/2015/376230, indexed in Pubmed: 25866777.

13. Bondre VP, Jadi RS, Mishra AC, et al. West Nile virus isolates from India: evidence for a distinct genetic lineage. J Gen Virol. 2007; 88(Pt 3): 875-884, doi: 10.1099/vir.0.82403-0, indexed in Pubmed: 17325360.

14. Prow NA, Hewlett EK, Faddy HM, et al. The Australian public is still vulnerable to emerging virulent strains of West Nile Virus. Front Public Health. 2014; 2: 146, doi: 10.3389/fpubh.2014.00146, indexed in Pubmed: 25279370.

15. Moureau G, Cook S, Lemey P, et al. New insights into flavivirus evolution, taxonomy and biogeographic history, extended by analysis of canonical and alternative coding sequences. PLoS One. 2015; 10(2): e0117849, doi: 10.1371/journal.pone.0117849, indexed in Pubmed: 25719412.

16. Kondrusik M, Ferenczi E, Zajkowska J, et al. [The evaluation of serum presence of antibodies reacting with West Nile Fever virus (WNV) antigens among inhabitants from Podlaskie and Swietokrzyskie region]. Przegl Epidemiol. 2007; 61(2): 409-416, indexed in Pubmed: 17956061.

17. Samorek-Salamonowicz E. Wirus Zachodniego Nilu — zagrożenie dla zdrowia publicznego. W: Niczyporuk J.S. (red.). Med Weterynaryjna 2008: 1368-1370.

18. Kilpatrick A, LaDeau S, Marra P. Ecology of West Nile Virus transmission and its impact on birds in the western hemisphere. The Auk. 2007; 124(4): 1121, doi: 10.1642/0004-8038(2007)124[1121:eownvt]2.0.co;2.

19. Samorek-Salamonowicz E, Niczyporuk JS. West Nile virus other emerging threats to public health. Post Mikrobiol. 2010; 49: 187-90.

20. Strauss JH, Strauss EG. Viruses and Human Disease, wyd. 2, Academic Press. 2007; 3: 118.

21. Arjona A, Wang P, Montgomery RR, et al. Innate immune control of West Nile virus infection. Cell Microbiol. 2011; 13(11): 1648-1658, doi: 10.1111/j.1462-5822.2011.01649.x, indexed in Pubmed: 21790942.

22. Colpitts TM, Conway MJ, Montgomery RR, et al. West Nile Virus: biology, transmission, and human infection. Clin Microbiol Rev. 2012; 25(4): 635-648, doi: 10.1128/CMR.00045-12, indexed in Pubmed: 23034323.

23. Konrad SK, Miller SN. Application of a degree-day model of West Nile virus transmission risk to the East Coast of the United States of America. Geospat Health. 2012; 7(1): 15-20, doi: 10.4081/ gh.2012.100, indexed in Pubmed: 23242676.

24. West Nile Fever [monograph on the internet]. Epi-News, National surveillance of communicable diseases: Statens Serum Institut; 2003. Available from: http://www ssi dk/English/News/EPI-NEWS/ /media/Indhold/EN\%20-\%20engelsk/EPI-NEWS/2003/ pdf/EPI-NEWS\%20-\%202003\%20-\%20No.; 204: ashx.

25. Kilpatrick AM, Meola MA, Moudy RM, et al. Temperature, viral genetics, and the transmission of West Nile virus by Culex pipiens mosquitoes. PLoS Pathog. 2008; 4(6): e1000092, doi: 10.1371/journal.ppat.1000092, indexed in Pubmed: 18584026.

26. West Nile Virus MONITOR Surveillance Maps- Clinical Cases and Asymptomatic Infections Canada, October 27, 2012, Public Health Agency of Canada, http://www.phac-aspc.gc.ca/wnv-vwn/ map-carte/map-carte-surv2012-eng.php.
27. Semenza JC, Tran A, Espinosa L, et al. Climate change projections of West Nile virus infections in Europe: implications for blood safety practices. Environ Health. 2016; 15 Suppl 1: 28, doi: 10.1186/s12940-016-0105-4, indexed in Pubmed: 26961903.

28. Pridjian G, Sirois PA, McRae S, et al. Prospective study of pregnancy and newborn outcomes in mothers with West nile illness during pregnancy. Birth Defects Res A Clin Mol Teratol. 2016; 106(8): 716-723, doi: 10.1002/bdra.23523, indexed in Pubmed: 27223334.

29. Hermanowska-Szpakowicz T, Grygorczuk S, Kondrusik M, et al. [Infections caused by West Nile virus]. Przegl Epidemiol. 2006; 60(1): 93-98, indexed in Pubmed: 16758745.

30. West Nile virus infection - Annual Epidemiological Report for 2018, https://www.ecdc.europa.eu/en/publications-data/west-nile-virus-infection-annual-epidemiological-report-2018.

31. Epidemiological update: West Nile virus transmission season in Europe, 2019, https://www.ecdc.europa.eu/en/news-events/ epidemiological-update-west-nile-virus-transmission-season-europe-2019.

32. Juricová Z, Pinowski J, Literák I, et al. Antibodies to alphavirus, flavivirus, and bunyavirus arboviruses in house sparrows (Passer domesticus) and tree sparrows (P. montanus) in Poland. Avian Dis. 1998; 42(1): 182-185, indexed in Pubmed: 9533098.

33. Hubálek Z, Wegner E, Halouzka J, et al. Serologic survey of potential vertebrate hosts for West Nile virus in Poland. Viral Immunol. 2008; 21(2): 247-253, doi: 10.1089/vim.2007.0111, indexed in Pubmed: 18433332.

34. Niczyporuk JS., Samorek-Salamonowic E. Study of the NRT-PCR method for the detection of the West Nile Virus. Bull Vet Inst Pulawy. 2009; 53: 187-192.

35. Kubica-Biernat B., Kruminis-Lozowska W., Stanczak J., Cieniuch S. A study on the occurrence of West Nile virus in mosquitoes (Diptera: Culicidae) on the selected areas in Poland. Wiad. Parazytol. 2009;55: 259-263.

36. Niczyporuk JS, Samorek-Salamonowicz E, Mizak WK. The survey of wild birds for West Nile virus in Poland. Pol J Vet Sci. 2011; 14(4): 573-577, doi: 10.2478/v10181-011-0085-9, indexed in Pubmed: 22439327.

37. Niczyporuk JS. Wirus Zachodniego Nilu w Polsce - realne zagrożenie w świetle doniesień prezentowanych na konferencji "Aktualne problemy dotyczące czynników zakaźnych przenoszonych przez krew”. J Transf Med. 2017; 10: 54-62.

38. Bażanów B, Jansen van Vuren P, Szymański P, et al. A survey on West Nile and Usutu viruses in horses and birds in Poland. Viruses. 2018; 10(2), doi: 10.3390/v10020087, indexed in Pubmed: 29462983.

39. Czupryna P, Niczyporuk J, Samorek-Salamonowicz E, et al. Poszukiwanie RNA wirusa Zachodniego Nilu w płynie mózgowo-rdzeniowym u osób chorych na zapalenie opon mózgowo-rdzeniowych z terenu województwa podlaskiego. Przegl Epidemiol. 2014; 68: 109.

40. Tylewska-Wierzbanowska S. Kleszczowe zapalenie mózgu u dzieci i dorosłych. Forum Pediatrii 2019; 5: 18-28.

41. Stefanoff P, Rogalska J, Zajkowska J, Czerska M, Seroka W, Czarkowski MP. Surveillance of aseptic central nervous system infections in Poland: is itmeeting is it objectives? Euro Surveill. 2011;16(29): pii:19924.

42. Zajkowska J, Czupryna P. Kleszczowe zapalenie mózgu — epidemiologia, patogeneza, obraz kliniczny, diagnostyka, profilaktyka i leczenie. Forum Zakażeń 2013; 4(1): 21-27.

43. Niczyporuk JS, Samorek-Salamonowicz E, Lecollinet S, et al. Occurrence of West Nile virus antibodies in wild birds, horses, 
Journal of Transfusion Medicine 2020, vol. 13, no. 4

and humans in Poland. Biomed Res Int. 2015; 2015: 234181, doi: 10.1155/2015/234181, indexed in Pubmed: 25866767.

44. Pancewicz S. Moniuszko-Malinowska A. Zakażenia wybranymi wirusami z rodziny Flaviviridae, Wydanie I. Białystok: Uniwersytet Medyczny; 2017: 69-90.

45. Jabłońska J, Popiel M, Bukowska-Ośko I, et al. No evidence of West Nile virus infection among Polish patients with encephalitis. Cent Eur J Immunol. 2016; 41(4): 383-385, doi: 10.5114/ ceji.2016.65137, indexed in Pubmed: 28450801.

46. Moniuszko-Malinowska A, Dunaj J, Czupryna P, et al. Absence of serological evidence for WNV presence in symptomatic patients in Poland. Infect Dis (Lond). 2019; 51(10): 782-784, doi: 10.1080/23744235.2019.1651453, indexed in Pubmed: 31402738.

47. Pealer LN, Marfin AA, Petersen LR, et al. West Nile Virus transmission investigation team. Transmission of West Nile virus through blood transfusion in the United States in 2002. N Engl J Med. 2003; 349(13): 1236-1245, doi: 10.1056/NEJMoa030969, indexed in Pubmed: 14500806.

48. Stramer SL, Dodd RY. AABB Transfusion-transmitted diseases emerging infectious diseases subgroup. Transfusion-transmitted emerging infectious diseases: 30 years of challenges and progress. Transfusion. 2013; 53(10 Pt 2): 2375-2383, doi: 10.1111/ trf.12371, indexed in Pubmed: 23926897.

49. Tobler LH, Bianco C, Glynn SA, et al. NHLBI Retrovirus Epidemiology Study (REDS). Detection of West Nile virus RNA and antibody in frozen plasma components from a voluntary market withdrawal during the 2002 peak epidemic. Transfusion. 2005; 45(4): 480-486, doi: 10.1111/j.0041-1132.2005.04266.x, indexed in Pubmed: 15819666.

50. Macedo de Oliveira A, Beecham BD, Montgomery SP, et al. West Nile virus blood transfusion-related infection despite nucleic acid testing. Transfusion. 2004; 44(12): 1695-1699, doi: 10.1111/j.0041-1132.2004.04130.x, indexed in Pubmed: 15584982.

51. Lai L, Lee TH, Tobler L, et al. Relative distribution of West Nile virus RNA in blood compartments: implications for blood donor nucleic acid amplification technology screening. Transfusion. 2012; 52(2): 447-454, doi: 10.1111/j.1537-2995.2011.03289.x, indexed in Pubmed: 21827506.

52. Mohr H, Knüver-Hopf J, Gravemann U, et al. West Nile virus in plasma is highly sensitive to methylene blue-light treatment. Transfusion. 2004; 44(6): 886-890, doi: 10.1111/j.1537-2995.2004.03424.x, indexed in Pubmed: 15157256.
53. Williamson LM, Cardigan R, Prowse CV. Methylene blue-treated fresh-frozen plasma: what is its contribution to blood safety? Transfusion. 2003; 43(9): 1322-1329, doi: 10.1046/j.1537-2995.2003.00483.x, indexed in Pubmed: 12919437.

54. Gallian P, Vignoli C, Dombey AM, et al. Inactivation of a European strain of West Nile virus in single- donor platelet concentrate using the INTERCEPT blood system. Vox Sang. 2006; 91(4): 345-347, doi: 10.1111/j.1423-0410.2006.00844.x, indexed in Pubmed: 17105611.

55. Lin L, Hanson CV, Alter HJ, et al. Inactivation of viruses in platelet concentrates by photochemical treatment with amotosalen and long-wavelength ultraviolet light. Transfusion. 2005; 45(4): 580-590, doi: 10.1111/j.0041-1132.2005.04316.x, indexed in Pubmed: 15819680.

56. Ruane PH, Edrich R, Gampp D, et al. Photochemical inactivation of selected viruses and bacteria in platelet concentrates using riboflavin and light. Transfusion. 2004; 44(6): 877-885, doi: 10.1111/j.1537-2995.2004.03355.x, indexed in Pubmed: 15157255.

57. West Nile virus infection Annual Epidemiological Report for 2018] - https://www.ecdc.europa.eu/sites/default/files/documents/west-nile-fever-annual-epidemiological-report-2018.pdf.

58. Weekly updates: 2019 West Nile virus transmission season https://www.ecdc.europa.eu/en/west-nile-fever/surveillance-and-disease-data/disease-data-ecdc.

59. West Nile Virus and Blood Safty Introduction to a Preparedness Plan in Europe. In: Prepared by: Greece I, Romania and France, ed. West Nile Virus and Blood Safty Introduction to a Preparedness Plan in Europe. Based on the EU Satellite Meeting of the Working Group on Blood Safety and WNV, Thessaloniki, 25-26 January; 2012: 2012.

60. West Nile Virus and Blood Safety Introduction to a Preparedness Plan in Europe. In: West Nile Virus and Blood Safety Introduction to a Preparedness Plan in Europe. Based on the EU Satellite Meeting of the Working Group on Blood Safety and WNV T, 27 January 2011, ed.; 2011.

61. European Directorate for the Quality of Medicines and Health Care of the Council of Europe (EDQM), wyd. 18.; 2020.

62. Measures to ensure blood safety during the WNV season. W: Meeting Report: Expert consultation on West Nile virus infection, Thessaloniki, 25-26 January 2011 [monograph on the internet]. European Centre for Disease Prevention and Control; 2011. http://ecdc.europa.eu/en/publications/Publications/1106_ MER_WNV_Expert_Consultation.pdf. 